\title{
THE TEMPERATURE OF HEALTHY DAIRY CATTLE.
}

By G. H. Wooldridge, M.R.C.V.S., Professor of Medicine, Royal Veterinary College of Ireland.

I HAVE been impressed on many occasions, when referring to the works of various observers, by the considerable differences in the average temperatures of apparently healthy cattle quoted by them, and also by the variations one might expect to meet with during health. Consequently, I determined to make observations with a view to ascertaining, as far as possible, the mean temperatures of healthy cattle taken per rectum, and the extremes between which they might be expected to fluctuate under normal conditions.

Robertson ${ }^{1}$ made observations on 352 cows and oxen, and gave IOI $9^{\circ} \mathrm{F} .\left(38.85^{\circ} \mathrm{C}\right.$.) as an average, with extremes of $100^{\circ}$ and $104.5^{\circ} \mathrm{F}$.

Singleton ${ }^{1}$ gives an average of IOI $^{\circ} 5^{\circ} \mathrm{F}$. $\left(38.6^{\circ} \mathrm{C}\right.$.), with extremes of $100^{\circ}$ and $103.3^{\circ} \mathrm{F}$. His observations number 100 .

Hobday $^{1}$ made observations on eighty-seven cows, and agreed with Singleton in the case of the mean temperature, viz. IOI $5^{\circ} \mathrm{F}$. ; but his range is a little lower, $99^{\circ} 5^{\circ} \mathrm{F}$. to $103^{\circ} \mathrm{F}$.

Fred. $\mathrm{Smith}^{2}$ gives IOI $8^{\circ} \mathrm{F}$. to $102^{\circ} \mathrm{F}$. $\left(38.7^{\circ} \mathrm{C}\right.$. to $38.8^{\circ} \mathrm{C}$.). Colin, ${ }^{3}$ Meade Smith, ${ }^{4}$ and Thanhoffer, ${ }^{5}$ all give identical figures, viz. $100^{\circ} \mathrm{F}$. to $10 \mathrm{I}^{\circ} 3^{\circ} \mathrm{F}$. $\left(38^{\circ} \mathrm{C}\right.$. to $38.5^{\circ} \mathrm{C}$.).

Frjedberger and Fröhner ${ }^{6}$ give IOI $8^{\circ}$ F. $\left(38.8^{\circ} \mathrm{C}\right.$.) as the average, and quote Hadschopulo, who took 50,000 temperatures at Moscow, and gave an average falling between $I_{0} I^{\circ}{ }^{\circ} \mathrm{F}$. and $10 \mathrm{I} 8^{\circ}\left(384^{\circ} \mathrm{C}\right.$. to $38 \cdot 8^{\circ} \mathrm{C}$.).

Thanhoffer ${ }^{7}$ also quotes Gavarret-Rosenthal, who states the very low average of $99^{\circ} 5^{\circ} \mathrm{F}$. $\left(37^{\circ} 5^{\circ} \mathrm{C}\right.$.).

On comparing these figures it will be seen that Robertson and Fred. Smith give a mean temperature of $1019^{\circ} \mathrm{F}$., which is $6^{\circ} \mathrm{F}$. higher than Colin and others give as the higher extreme. Again, comparing the averages of Robertson and Gavarret-Rosenthal, we find a difference of almost $2.5^{\circ} \mathrm{F}$, the former giving $1019^{\circ} \mathrm{F}$, and the latter $99^{\circ} 5^{\circ} \mathrm{F}$.

The observations I have recorded were all made on apparently healthy dairy cattle. They number I395, and were made on I74 animals. I shall presently draw attention to the fact that a large proportion of these animals were subsequently submitted to the tuberculin test, and that many of them reacted. But it is advisable first to see what their average temperature is, in order to compare it with those quoted by previous observers who omit to state whether the subjects of their observations were proved free from tuberculosis, in which case $I$ think it is fair to conclude that they come under the same heading of "apparently healthy" animals. I find, then, that the average temperature of these 1395 observations is IoI $^{\circ} 6^{\circ} \mathrm{F}$. $\left(38.66^{\circ} \mathrm{C}\right.$.), which is $\mathrm{I}^{\circ} \mathrm{F}$. higher than Hobday and Singleton give, and $33^{\circ}$ higher than Colin and others give as the higher extreme.

\footnotetext{
1 Quoted by Schäfer, "Text-book of Physiology," p. 790

2 "Veterinary Physiology," p. 306.

3 "Traité de Physiologie Comparée des Animaux, vol. i., p. 1046

4 "Physiology of the Domesticated Animals," p. 696.

5 "Vergleichende Physiologie und Histologie," pp. 476, 477.

6 "Lehrbuch der Klinischen Untersuchungsmethoden," p. 166.

7 op. cit., pp. 476, 477.
} 
Much greater importance, however, must be attached to the statistics based on observations made on animals proved to be free from tuberculosis, which is often responsible for considerable fluctuations. I know of no such observations previously recorded. In fact, nearly all the statistics we have were compiled before tuberculin was introduced into regular practice; and its use is the only definite method we have of detecting most of the early cases of the disease.

Of the previously mentioned animals, 63 of those tested failed to react to the tuberculin, and were consequently considered to be free. On those 63 animals I have 520 observations; and the average temperature $I$ find to be $10 \mathrm{I}^{\circ} 4^{\circ} \mathrm{F} .\left(38.5^{\circ} \mathrm{C}.\right)$, The lowest recorded temperature of the 520 was $1004^{\circ} \mathrm{F} .\left(38^{\circ} \mathrm{C}.\right)$, and the highest observed was $102.8^{\circ} \mathrm{F} .\left(39^{\circ} 3^{\circ} \mathrm{C}\right.$.) ; but these extremes were very rarely indeed met with. The lowest average of any individual was $100.8^{\circ} \mathrm{F}$, and the highest average was $102.2^{\circ} \mathrm{F}$.

Of the 63 healthy animals, only 7 had an average temperature below $10 I^{\circ} \mathrm{F}$; and the same number had an average temperature of $102^{\circ} \mathrm{F}$, or over.

Thus, my conclusion is, that in healthy dairy cattle the temperature mày vary between $100^{\circ} 4^{\circ} \mathrm{F}$. and $102.8^{\circ} \mathrm{F}$, with an average mean temperatue of $\mathrm{IOI}^{\circ} 4^{\circ} \mathrm{F}$.

\section{Some Causes of Variations.}

Time of Day.-Some of the causes and the extent of the variations of temperature in health are well worthy of note; and therefore I made 370 observations on a dairy of 37 apparently healthy cows, some in calf, and others not in calf. The temperatures were taken twice daily for five consecutive days: in the mornings, about 8 o'clock, and in the afternoons, between 4 and 5 o'clock, before feeding. The average morning temperature of 185 observations was $101.5^{\circ} \mathrm{F}$, and the average evening temperature was $\mathrm{IO}^{\circ} \mathrm{F}$. Thus we see an average rise of $5^{\circ} \mathrm{F}$. from morning to evening.

Feeding is usually credited with some slight influence in raising the temperature. In order to see to what extent this occurred, I took the temperatures of the same 37 cows during feeding between 4.30 and 5 P.M. The average temperature at that time was found to be $102.3^{\circ} \mathrm{F}$. As the average temperature of rest of the same animals at the same hour on other days was found to be $102^{\circ} \mathrm{F}$., it is permissible to assume that feeding was responsible for an average rise of temperature of $3^{\circ} \mathrm{F}$.

Drinking, immediately after taking the temperature, is usually responsible for a slight reduction; but I have no records at hand to show to what extent.

Pregnancy.-To see the extent of the rise caused by this condition, I made 60 observations on 6 apparently healthy, in-calf cows. Their average was $102^{\circ} \mathrm{F}$. On comparing that with 310 observations made on 3 I non-pregnant cows kept in the same cow-shed at the same time, the average of the latter being IOI $7^{\circ} \mathrm{F}$, a rise of $3^{\circ} \mathrm{F}$. is shown, presumably due to their pregnant condition.

Various other conditions are said to cause variations of temperature in health, such as oestrum, rumination, active lactation, 
housing, and the time of year. Hadschopulo states that, in cold weather, the temperature per rectum is raised from $2^{\circ}$ to $4^{\circ} \mathrm{F}$. (Quoted by Friedberger and Fröhner).

All these observations were made on housed dairy cattle. I hope at some future date to be able to record the results of observations made on store cattle kept outside.

\section{The Temperature of Tuberculous Dairy Cattle not Clinically Affected.}

It has long been an accepted fact that the temperature is of little assistance to the clinical observer in making his diagnosis in cases of tubcrculosis in cattle by ordinary means; and one is not infrequently astonished, on examining the viscera of cattle in prime condition slaughtered for food, to find tuberculous lesions when least expected. Friedberger and Fröhner" say, "The temperature of the body in tuberculosis may be normal, although we far more frequently find an irregular remittent or even intermittent fever up to $4 \mathrm{I}^{\circ} \mathrm{C}$. $\left(\mathrm{IO} 58^{\circ} \mathrm{F}\right.$.) . . . Clinical diagnosis is very uncertain. No diagnostic sign may be present, especially during the first few months of the disease."

Since the introduction of tuberculin as a diagnostic agent, however, tuberculosis may be detected in the very earliest stages, and where there has been no reason to suspect the presence of the disease. Tuberculin has now been in use for nearly fifteen years, and during that period has had a very extensive trial and proved itself to be almost infallible.

The observations here recorded were made on dairy cows that were not suspected of tuberculosis, which disease was only revealed by submitting the animals to the tuberculin test.

My observations number 505, and were made on 74 reacting dairy cows out of 137 tested. The temperature of each of the cows was taken on several consecutive days, and at various times of the day, and they were tested immediately afterwards. Obviously the temperature of these animals during the test period must not be included, since the reaction consists of a rise of temperature. The average temperature shown by the 505 observations is IOI $7^{\circ} \mathrm{F}$. $\left(38.7^{\circ} \mathrm{C}\right.$.), which is $3^{\circ} \mathrm{F}$. higher than the average temperature of health. The lowest observed temperature was $1004^{\circ} \mathrm{F}$, and the highest was $1043^{\circ} \mathrm{F}$. The lowest average temperature of an individual was $100^{\circ} \mathrm{F}$, and the highest average was $103.3^{\circ} \mathrm{F}$. The greatest range of any individual observed was from $100.7^{\circ} \mathrm{F}$. to $1043^{\circ}$ F.; while the average of fifteen observations on that same cow was found to be $1022^{\circ} \mathrm{F}$. Of the 74 cows in question, 50 per cent. had an average temperature falling between $I O I^{\circ} \mathrm{F}$. and $102^{\circ} \mathrm{F}$, while Io averaged below $101^{\circ} \mathrm{F}$, and 27 averaged $102^{\circ} \mathrm{F}$. or over.

Thus, I am justified in concluding that tuberculosis in early cases causes only a slight rise in the average temperature, viz., $3^{\circ} \mathrm{F}$. but that affected animals are subject to greater variations from day to day than non-tuberculous cows kept under similar conditions.

A rather startling side-issue is revealed by the testing of these 137 cows, and that is the enormously large proportion of apparently healthy animals that reacted, viz., 74 out of 137 , or 54 per cent. 